\title{
Prognostic and Diagnostic Significance of SDPR-Cavin-2 in Hepatocellular Carcinoma
}

\author{
Wei Jing ${ }^{a}$ Ping Luo ${ }^{a}$ Man Zhu ${ }^{a}$ Qian Aib Hongyan Chai ${ }^{\mathrm{a}}$ Jiancheng Tu \\ aDepartment of Clinical Laboratory Medicine and Center for Gene Diagnosis, Zhongnan Hospital of \\ Wuhan University, Wuhan, bHubei Institute for Nationalities, Enshi, China
}

\author{
Key Words \\ Cavins $•$ Cavin-2 $\bullet$ HCC $・$ Prognosis $・$ Diagnosis
}

\begin{abstract}
Background: Hepatocellular carcinoma (HCC) is a malignant tumor worldwide. Due to the lack of early prediction marker, numerous patients were diagnosed in their late stage. The family of cavins plays important roles in caveolae formation and cellular processes. Cavin-2, one of the members of cavins, has been reported as a suppresser in cancers. In this study, we have investigated its expression pattern and clinical significance in HCC. Methods: RT-qPCR was performed to detect the expression of cavin-2. Results: Cavin-2 was down-regulated in HCC and associated with tumor differentiation ( $r=-0.275, P=0.013)$ and tumor-nodemetastasis (TNM) stage $(r=-0.216, P=0.035)$. The Overall survival analysis showed that patients with lower cavin-2 expression had a relatively poor prognosis. Meanwhile, the multivariate analysis revealed that cavin-2 was an independent prognostic factor. The receiver operating characteristic curve analyses indicated that plasma cavin-2 presented a high accuracy ( $A U C=0.727,0.865,0.901$ ) for diagnosing HCC cases from controls, hepatitis B and cirrhosis patients, respectively. Meanwhile, plasma cavin-2 showed a high sensitivity $(88.4 \%, 89.9 \%)$ for detecting HCC with the serum $\alpha$-fetoprotein (AFP) levels below $200 \mathrm{ng} / \mathrm{ml}$ from those hepatitis $B$ and cirrhosis cases. Conclusion: Our data suggested that cavin-2 might be considered as a potential prognostic and diagnostic indicator in HCC.
\end{abstract}

\section{Introduction}

Hepatocellular carcinoma (HCC) is one of the malignant tumors, which is also the second death-related diseases in humans worldwide [1]. HCC is the predominant form of liver cancer, accounting for $85 \%$ to $90 \%$ in all liver cancer cases [2]. $80 \%$ to $90 \%$ of the HCC

W. Jing and P. Luo contributed equally to this work. 
patients have an established background of cirrhosis [3]. The major risk factor of cirrhosis is infected with hepatitis B virus (HBV), especially in Asia and Sub-Saharan Africa [4]. At present, HCC can be treated by kinds of treatments, including surgery, liver transplantation, chemotherapy and interventional therapy [5]. However, as most HCC is diagnosed in the advanced stage, the rate of 5 -year survival is only $7 \%[6,7]$. Recurrence and metastasis are the main causes of low survival rate [8]. The serum $\alpha$-fetoprotein (AFP) has long been used as a prognostic marker for HCC diagnosis. However, even in 15\%-30\% advanced patients, the AFP levels remain normal, leading to a high negative rate $[9,10]$. Despite the specificity and sensitivity of the early diagnosis of HCC was improved quite bit by CT and MRI, the accuracy is still determined by the ability to discriminate between tumor and non-neoplastic lesions [11]. Up to now, we are short of good early diagnostic and predictive markers for HCC $[12,13]$. Thus, it is necessary for us to seek a reliable marker.

Cavins are a new family of membrane proteins, which play an important role in caveolae formation $[14,15]$. It has been reported that caveolae and its major components, known as caveolins, are involved in a variety of cellular processes including endocytosis, lipid homeostasis, signal transduction and tumorigenesis [16]. Recently, studies elaborated that cavins are able to stabilize the caveolae structure and regulate the availability of caveolins $[17,18]$. So far, cavins have been identified with four different proteins, consisting of cavin-1 (polymerase transcript release factor, PTRF), cavin-2 (serum deprivation protein response, SDPR), cavin-3 (Sdr-related gene product that binds to c-kinase, SRBC), and cavin-4 (musclerestricted coiled-coil protein, MURC) [19]. Comparing with cavin-1 and cavin-2, cavin-3's function was not well established and cavin-4 was related to caveolin-associated muscle disease [16, 20]. In 2015, Regazzetti et al. [21] found that cavin-1 and cavin-2 were necessary for the formation of caveolae. Therefore, researchers supposed that cavin- 1 and cavin-2 may be related to tumorigenesis, one of the functions of caveolae. In 2012, Bai et al. [22] found that cavin-1 was inactivated in breast cancer, and the down-regulation of cavin- 1 in breast cancer cells was associated with the promoter methylation. Meanwhile, Nassar et al. [23] demonstrated that the absence of cavin-1 in prostate cancer cells significantly led to tumor progression and metastasis in 2013. However, researches on cavin-2 have been limited to its role as a regulator of caveolae formation, while the potential value in tumors has not been deeply carried out [15].

Cavin-2 (serum deprivation protein response, SDPR) maps to chromosome 2q32-33, which shares more than $20 \%$ similarities with cavin-1, and is firstly shown in vitro to be a substrate for protein kinase C (PKC) isoforms by Burgener in 1990 [24]. The PKC was known to play an important role in progression of HCC [25] and Hansen et al. [15] demonstrated that cavin-2 was essential for the expression levels of cavin-1 protein which had a function in the development of tumors. Thus, we hypothesized that there was a correlation between cavin- 2 and tumors. In 2013, Altintas et al. [26] found that cavin- 2 could be considered as genes protective against prostate cancer and involved in the early stages of prostate carcinogenesis. Meanwhile, previous studies indicated that the levels of cavin-2 were not only down-regulated in prostate cancer but also in kidney and breast cancers $[27,28]$. However, there has not been reported that the clinical and prognostic significance of cavin- 2 expression in HCC.

In the present study, we investigated the levels of cavin-2 in HCC patients, then analyzed the relationship between cavin-2 expression and clinical characteristics, and evaluated the prognostic and diagnostic value of cavin-2. In conclusion, our aim was to provide an important basis for prognosis and diagnosis in HCC patients.

\section{Materials and Methods}

Specimens

91 patients (83 males and 8 females, mean age 55 \pm 10 ) with HCC and adjacent normal liver tissues were recruited in the Zhongnan Hospital of Wuhan University from 2011 to 2015, who underwent surgery 


\section{Cellular Physiology Cell Physiol Biochem 2016;39:950-960 \begin{tabular}{l|l|l|}
\hline DOI: 10.1159/000447803 & $\begin{array}{l}\text { C) } 2016 \text { The Author(s). Published by S. Karger AG, Basel } \\
\text { www.karger.com/cpb }\end{array}$ \\
\hline
\end{tabular} \\ Jing et al.: Prognostic and Diagnostic Significance of Cavin-2 in HCC}

without preoperative chemotherapy or radiotherapy. All of the patients were selected based on pathology reports. Tumor staging (stage I, II, III and IV) was defined according to the seventh edition of the AJCC Cancer Staging Manual. Tumor specimens and corresponding adjacent non-tumor tissues were stored at $-80{ }^{\circ} \mathrm{C}$ in RNAlater ${ }^{\circledR}$ RNA Stabilization Solution (Invitrogen, CA, USA). Follow-up data ranged from 2 to 48 months. Clinical and follow-up data were collected, and no information that could identify the patients was included.

Whole blood samples of 189 patients were obtained from Zhongnan Hospital of Wuhan University between 2014 and 2015, and divided into three groups: 71 patients with HCC (58 males and 13 females,

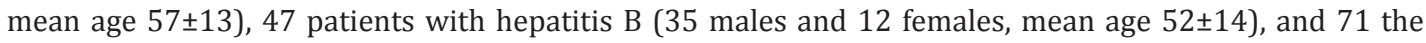
cirrhosis (52 males and 19 females, mean age 56 \pm 12 ), which were collected in EDTA tubes and centrifuged at $2,000 \mathrm{~g}$ for $5 \mathrm{~min}$ at $4{ }^{\circ} \mathrm{C}$ to spin down the blood cells. The supernatants were transferred to microcentrifuge tubes and centrifuged at $12,000 \mathrm{~g}$ for $5 \mathrm{~min}$ at $4{ }^{\circ} \mathrm{C}$. The plasma was then stored at $-80{ }^{\circ} \mathrm{C}$ until use. Patients who underwent preoperative chemotherapy or radiotherapy before were excluded. Meantime, 69 healthy blood samples (54 males and 15 females, mean age 54 11 ) were collected from the Physical Examination Center. All the controls were without hepatitis, hepatic diseases or abnormal liver biochemical outcome.

\section{Ethical approval}

Tissue and plasma specimens and clinical materials were collected after obtaining the informed consent of patients in accordance with institutional ethical guidelines, which was all approved by the Ethics Committee of Zhongnan Hospital of Wuhan University (Wuhan, China).

\section{RNA extraction and reverse transcription}

Trizol reagent (Invitrogen, CA, USA) was used to extract total RNA from tissues, and Total RNA Seperate Extraction Kit (Bioteke, Beijing, China) was used in plasma. The concentration and purity of RNA were quantified by NanoDrop ND2000 (Thermo, CA, USA). RNA was reverse transcribed to cDNA by using PrimeScript ${ }^{\mathrm{TM}} \mathrm{RT}$ reagent Kit with gDNA Eraser (Takara, Japan), following: $42{ }^{\circ} \mathrm{C}$ for 2 min, and then $37^{\circ} \mathrm{C}$ for $15 \mathrm{~min}, 85^{\circ} \mathrm{C}$ for $5 \mathrm{sec}$.

\section{Real-Time PCR Analysis}

According to manufacturer's instructions, the levels of cavin-2 were performed on the Bio-Rad CFX96 (Bio-Rad Laboratories, Inc., Hercules, CA, USA) using SYBR-green I Premix EXTaq. The reactions started at $95^{\circ} \mathrm{C}$ for $5 \mathrm{~min}$, followed by 40 cycles of $95^{\circ} \mathrm{C}$ for $30 \mathrm{~s}, 59^{\circ} \mathrm{C}$ for $30 \mathrm{~s}$ and $72^{\circ} \mathrm{C}$ for $30 \mathrm{~s}$. In order to normalize the results for the qPCR, the GAPDH expression was used. The synthesized primers were as follows: cavin-2 (forward: 5'-AAGAGCGCATGGATAGGCAG-3' and reverse: 5'-TCATCGTGGGGCAAATCATCA-3'); GAPDH (forward: 5'-AGAAGGCTGGGGCTCATTTG-3' and reverse: 5'- GCAGGAGGCATTGCTGATGAT-3'). All experiments were carried out in duplicate for each data point. Relative gene expression levels were calculated using the comparative $C$ t method formula $2^{-\Delta C \mathrm{t}}$.

\section{Statistical Analysis}

All statistical analyses were carried out using the SPSS version 17.0 (SPSS, Inc. Chicago, IL, USA) and GraphPad Prism 5.0 (GraphPad Software, La Jolla, CA, USA). All the data were presented in our study as mean \pm standard deviation $(\mathrm{M} \pm \mathrm{SD}$ ) or median $(\mathrm{QR}) . P<0.05$ was considered to be statistically significant. Statistical significance was assigned at $P<0.05\left(^{*}\right)$ or $P<0.01\left({ }^{* *}\right)$. The Shapiro-Wilk test was carried out to check the normality of the distribution. The normally distributed numeric variables were evaluated by Student's $t$-test, while non-normally distributed variables were analyzed by Kruskal-Wallis variance analysis. Correlations were analyzed using the Spearman correlation. Survival curves were estimated by the KaplanMeier method and the log-rank test was used to estimate the statistical differences between survival curves. The multivariate analysis including the variables with a $P<0.05$ in univariate analysis was used to assess the Cox proportional hazards model. Oneway ANOVA was used to validate the different cavin-2 expression among subgroups in plasma. The categorical variables were analyzed using Chi-square test. Finally, the receiver operating characteristic (ROC) curve analysis was performed to estimate the diagnostic values. 


\begin{tabular}{|c|c|}
\hline Cellular Physiology & Cell Physiol Biochem 2016;39:950-960 \\
\hline Dischomict & \begin{tabular}{l|l} 
DOI: 10.1159/000447803 \\
Published online: August 12, 2016
\end{tabular} $\begin{array}{l}\text { 2016 The Author(s). Published by S. Karger AG, Basel } \\
\text { www.karger.com/cpp }\end{array}$ \\
\hline
\end{tabular}

\section{Results}

Cavin-2 was significantly down-regulated in HCC tissue specimens

The expression levels of cavin-2 were measured by RT-qPCR in 91 paired clinical HCC tissues and adjacent normal liver tissues (Fig. 1). Expression of cavin-2 relative to GAPDH in tumor tissues was significantly down-regulated than in non-tumor tissues $(P<0.01$; Fig. $1 \mathrm{~A})$. The result indicated that cavin-2 may play a tumor suppressor's role in HCC.

\section{Correlation between cavin-2 and clinic variables}

Then studies were carried on assessing the correlation between cavin- 2 and clinical characteristics. No statistically significant relevancies were found in gender, age, smoking, alcoholism, tumor size, cirrhosis, the serum $\alpha$-fetoprotein (AFP), HBV-DNA and other biochemistry indexes. However, the levels of cavin-2 expression were correlated with differentiation ( $\mathrm{r}=-0.275, P=0.013)$ and tumor-node-metastasis (TNM) stage ( $\mathrm{r}=-0.216$, $P=0.035$ ) (Table 1 and Table 2). Thus, down-regulation of cavin-2 might have an important role in HCC development and progression.

\section{Association between cavin-2 levels and patients' survival}

To answer whether the levels of cavin-2 expression correlated to the outcome of HCC patients, the 91 HCC patients were divided into two groups: relative high-cavin-2 group ( $\mathrm{n}=46$, cavin -2 expression $\geq$ median) and relative low-cavin- 2 group $(\mathrm{n}=45$, cavin- 2 expression < median) according to the median expression of cavin-2 (0.0092) (Fig. 2 A). Then survival signatures were analyzed in 67 patients, and 30 of them were in the high expression group, the others were in the low group. In patients' survival analyses, overall survival (OS) was calculated following the Kaplan-Meier method and log-rank test. Significantly, the low-cavin-2 group had a shorter survival time (median OS: 28 months), comparing with high-cavin-2 group (median OS: 40 months) (Fig. 2 B), suggesting the absence of cavin-2 expression could represent a novel indicator of poor prognosis in HCC.

In univariate analysis, differentiation, TNM stage and the levels of cavin-2 were significantly associated with overall survival of HCC patients $(P<0.05$, Table 3$)$. Then, we confirmed that differentiation, TNM stage and the levels of cavin-2 were independent prognostic predictors for overall survival of HCC patients by the multivariate analysis using Cox regression model $(P<0.05$, Table 3).

\section{Cavin-2 expression in plasma among subgroups}

Table 4 summarized the main demographic and clinical characteristics of studied subjects. No difference was observed in important risk factors including gender, age,

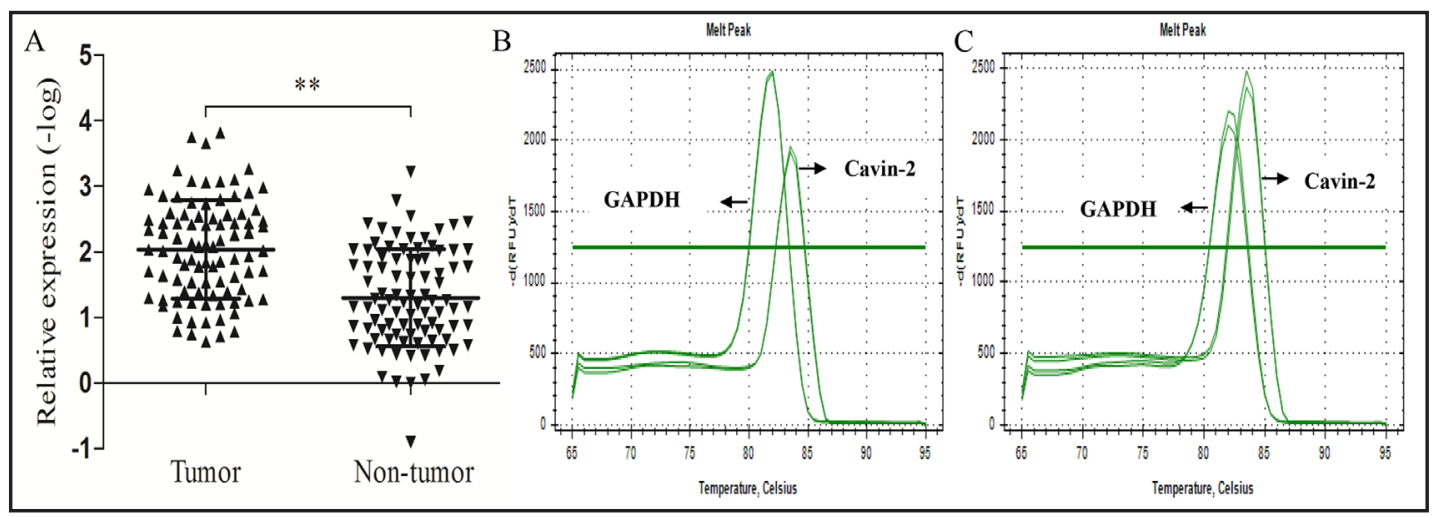

Fig. 1. Cavin-2 expression in HCC tissues and adjacent normal liver tissues. A. Cavin-2 levels in tumor tissues were significantly lower than in nontumor tissues. B. The melt curve of cavin-2 and GAPDH in HCC tissues. C. The melt curve of cavin-2 and GAPDH in nontumor tissues. Results were expressed as mean \pm SD. All data analyzed using Student's t test. ${ }^{* *} P<0.01$.

\section{KARGER}


Table 1. Association of cavin-2 expression with clinical parameters in HCC. Abbreviation: Data are mean \pm SD. ${ }^{*} p<0.05$, ** $p<0.01$; HCC, hepatocellular carcinoma; TNM, tumor-node-metastasis; HBV, hepatitis $B$ virus; AFP, $\alpha$-fetoprotein; ALT, alanine aminotransferase; AST, aspartate aminotransferase; GGT, $\gamma$-glutamyl transferase; GLU, glucose

\begin{tabular}{|c|c|c|c|c|}
\hline \multirow[b]{2}{*}{ Characteristics } & \multirow[b]{2}{*}{$\mathrm{n}$} & \multicolumn{3}{|c|}{ cavin-2 relative expression (-log) } \\
\hline & & Mean \pm SD & $t$ & \\
\hline Tissue** & & & 9.511 & $<0.001$ \\
\hline $\mathrm{HCC}$ & 91 & $2.04 \pm 0.75$ & & \\
\hline Adjacent non-cancerous liver & 91 & $1.30 \pm 0.74$ & & \\
\hline Gender & & & -0.834 & 0.407 \\
\hline Male & 83 & $2.02 \pm 0.77$ & & \\
\hline Female & 8 & $2.25 \pm 0.57$ & & \\
\hline Age & & & -1.163 & 0.248 \\
\hline$<55$ & 41 & $1.95 \pm 0.82$ & & \\
\hline$\geqq 55$ & 50 & $2.14 \pm 0.65$ & & \\
\hline Smoking & & & 1.019 & 0.311 \\
\hline Negative & 53 & $2.11 \pm 0.77$ & & \\
\hline Positive & 38 & $1.94 \pm 0.73$ & & \\
\hline Alcoholism & & & 1.402 & 0.164 \\
\hline Negative & 68 & $2.10 \pm 0.74$ & & \\
\hline Positive & 23 & $1.85 \pm 0.76$ & & \\
\hline Differentiation* & & & -2.541 & 0.013 \\
\hline High/ Moderate & 68 & $2.02 \pm 0.75$ & & \\
\hline Low & 12 & $2.51 \pm 0.66$ & & \\
\hline Tumor Size & & & -0.220 & 0.826 \\
\hline$<10 \mathrm{~cm}$ & 51 & $2.03 \pm 0.77$ & & \\
\hline$\geqq 10 \mathrm{~cm}$ & 40 & $2.07 \pm 0.71$ & & \\
\hline Tumor nodes & & & 0.707 & 0.482 \\
\hline Single & 67 & $2.01 \pm 0.78$ & & \\
\hline Multi & 24 & $1.81 \pm 0.63$ & & \\
\hline TNM stage* & & & -2.152 & 0.035 \\
\hline $\mathrm{I} \sim \mathrm{II}$ & 46 & $1.80 \pm 0.64$ & & \\
\hline III $\sim$ IV & 45 & $2.16 \pm 0.75$ & & \\
\hline HBV DNA $(\mathrm{IU} / \mathrm{ml})$ & & & -0.270 & 0.789 \\
\hline$<500$ & 12 & $2.09 \pm 0.78$ & & \\
\hline$\geqq 500$ & 26 & $2.17 \pm 0.75$ & & \\
\hline Cirrhosis & & & 1.785 & 0.078 \\
\hline Negative & 47 & $2.17 \pm 0.77$ & & \\
\hline Positive & 44 & $1.89 \pm 0.71$ & & \\
\hline AFP (ng/ml) & & & -0.610 & 0.543 \\
\hline$<200$ & 37 & $1.93 \pm 0.79$ & & \\
\hline$\geqq 200$ & 40 & $2.04 \pm 0.72$ & & \\
\hline ALT (U/l) & & & -1.195 & 0.235 \\
\hline$<46$ & 49 & $1.95 \pm 0.78$ & & \\
\hline$\geqq 46$ & 42 & $2.14 \pm 0.71$ & & \\
\hline AST (U/I) & & & -1.599 & 0.113 \\
\hline$<46$ & 44 & $1.91 \pm 0.73$ & & \\
\hline$\geqq 46$ & 47 & $2.16 \pm 0.75$ & & \\
\hline GGT $(\mathrm{U} / \mathrm{I})$ & & & -0.079 & 0.937 \\
\hline$<55$ & 34 & $1.98 \pm 0.69$ & & \\
\hline$\geqq 55$ & 46 & $1.99 \pm 0.79$ & & \\
\hline GLU (mmol/l) & & & -1.556 & 0.123 \\
\hline$<6.2$ & 67 & $1.96 \pm 0.72$ & & \\
\hline$\geqq 6.2$ & 24 & $2.24 \pm 0.83$ & & \\
\hline
\end{tabular}

Table 2. Correlation analysis of cavin-2 in relation to clinical parameters

\begin{tabular}{lc}
\hline Characteristics & Correlation Coefficient \\
\hline Differentiation (High/ Moderate vs Low) & -0.275 \\
TNM stage $(\mathrm{I} \sim$ II $v s$ III $\sim$ IV) & -0.216 \\
\hline
\end{tabular}

smoking, alcoholism and glucose (GLU) in the four groups. There was a significant difference in alanine aminotransferase (ALT), aspartate aminotransferase (AST) among the groups.

To evaluate the value of cavin- 2 as a biomarker, the levels of plasma target mRNA in 71 HCC patients, 47 hepatitis B, 71 cirrhosis patients, and 69 control cases were measured by RT-qPCR. The result indicated that the expression of cavin-2 in HCC was lower than that in hepatitis $\mathrm{B}$, cirrhosis and control groups (HCC vs cirrhosis: $P<0.001$; HCC vs hepatitis B: $P<0.001$; HCC vs the controls: $P<0.001$ ). However, comparing the levels of the controls, 
Fig. 2. Overall survival according to cavin-2 expression levels. Patients with decreased cavin-2 expression (median OS: 28 months) showed reduced survival time compared with patients with high levels of cavin-2 expression (median OS: 40 months $)(P<0.01)$. Data analyzed using log-rank test.

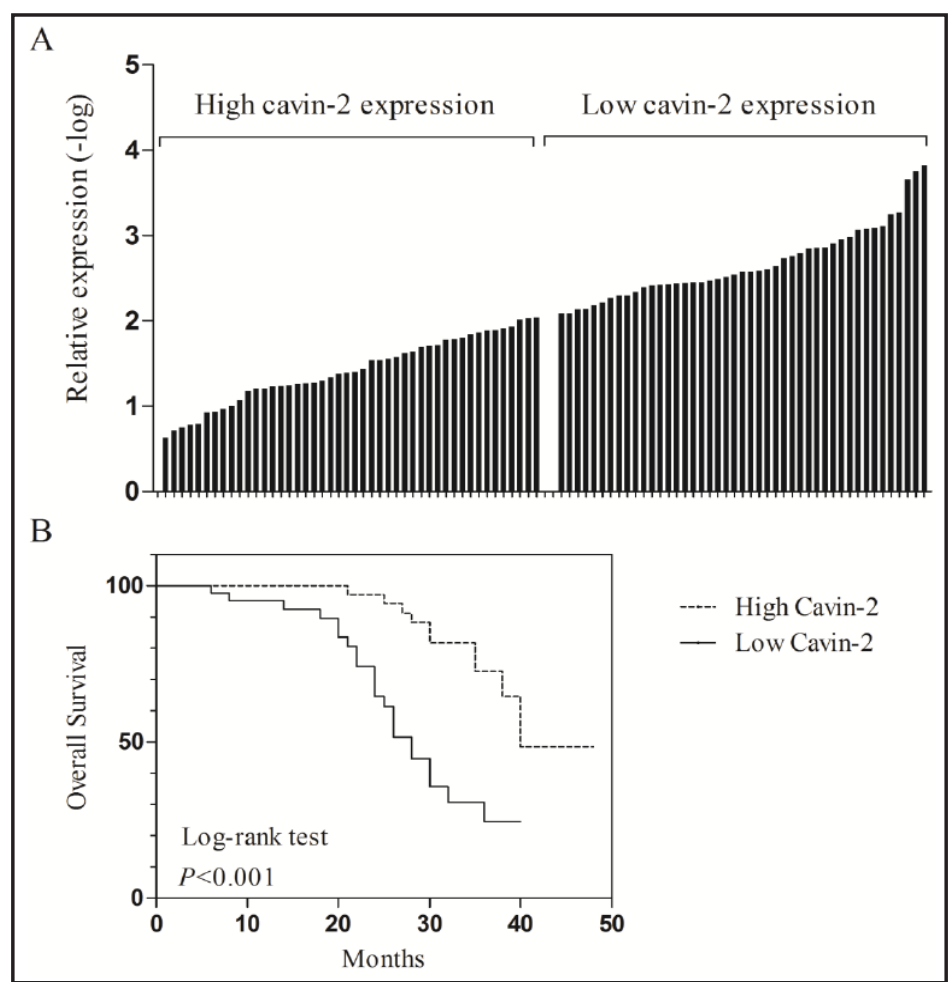

Table 3. Prognostic factors in Cox proportional hazards model. Abbreviation: $P<0.05$ was considered statistically significant; ALT, alanine aminotransferase; AST, aspartate aminotransferase; AFP, $\alpha$-fetoprotein; TNM, tumor-node-metastasis

\begin{tabular}{lcccc}
\hline \multirow{2}{*}{ Factors } & \multicolumn{2}{c}{ Univariate analysis } & \multicolumn{2}{c}{ Multivariate analysis } \\
& HR $(95 \% \mathrm{CI})$ & $P$ & HR $(95 \% \mathrm{CI})$ & $P$ \\
\hline Gender & $2.481(0.511-4.291)$ & 0.469 & \\
Age & $0.992(0.955-1.031)$ & 0.689 & \\
Smoking & $0.910(0.454-1.827)$ & 0.791 & \\
Alcoholism & $0.992(0.458-2.148)$ & 0.984 & \\
Cirrhosis & $1.049(0.521-2.110)$ & 0.894 & \\
Tumor size & $2.054(0.943-4.471)$ & 0.070 & \\
Tumor number & $1.471(0.657-3.293)$ & 0.348 & \\
ALT & $1.420(0.697-2.892)$ & 0.334 & & \\
AST & $1.728(0.859-3.474)$ & 0.125 & & \\
AFP & $1.546(0.714-3.348)$ & 0.269 & & \\
Differentiation (low vs high/ moderate) & $3.141(1.474-6.694)$ & 0.003 & $2.504(1.147-5.466)$ & 0.021 \\
TNM (III IV vs I II ) & $3.033(1.360-6.767)$ & 0.007 & $3.156(1.389-7.170)$ & 0.006 \\
Cavin-2 expression (low vs high) & $4.145(1.940-8.853)$ & $<0.001$ & $4.225(1.935-9.224)$ & $<0.001$ \\
\hline
\end{tabular}

we found that the levels in hepatitis $B$ and cirrhosis groups were higher than the controls (cirrhosis vs controls: $P<0.001$; hepatitis B vs controls: $P<0.05$ ). In addition, no remarkable difference was observed for cavin-2 between hepatitis B and cirrhosis (hepatitis B vs cirrhosis: $P=0.16$ ) (Fig. 3).

\section{Diagnostic value of cavin-2 in plasma}

To assess whether plasma cavin-2 could be used as a potential diagnostic marker for HCC, ROC was constructed using 5 models: HCC vs the controls, HCC vs hepatitis B, HCC vs cirrhosis, hepatitis B vs controls and cirrhosis vs controls (Table 5). Result revealed that cavin-2 had a good sensitivity of $85.9 \%$ (AUC=0.727, 95\%CI: 0.643-0.812) (Fig. 4A) in discriminating HCC patients from the controls. Meanwhile, the area under the ROC $\left(\mathrm{AUC}_{\mathrm{ROC}}\right)$ showed that cavin-2 could be thought of as a better diagnostic value for differentiating HCC patients from hepatitis B (AUC=0.865, 95\%CI: 0.796-0.934) (Fig.4 B) and from cirrhosis (AUC $=0.901,95 \%$ CI: 0.849-0.952) (Fig. 4 D). Moreover, ROC result indicated that plasma 

Cellular Physiology Cell Physiol Biochem 2016;39:950-960 \begin{tabular}{cl|l} 
DOI: 10.1159/000447803 & $\begin{array}{l}\text { O 2016 The Author(s). Published by S. Karger AG, Basel } \\
\text { www.karger.com/cpb }\end{array}$ \\
and Biochemistry Published online: August 12, 2016 &
\end{tabular}

Jing et al.: Prognostic and Diagnostic Significance of Cavin-2 in HCC

Table 4. Characteristics of the studied subjects. Abbreviation: \# Median (25 Percentiles, 75 Percentiles); ${ }^{a}$ Chi-square test. ${ }^{b}$ Kruskal-Wallis; ALT, alanine aminotransferase; AST, aspartate aminotransferase; GLU, glucose

\begin{tabular}{|c|c|c|c|c|c|}
\hline Characteristics & $\begin{array}{c}\mathrm{HCC} \\
\mathrm{N}=71\end{array}$ & $\begin{array}{c}\text { Hepatitis B } \\
N=47\end{array}$ & $\begin{array}{c}\text { Cirrhosis } \\
N=71\end{array}$ & $\begin{array}{c}\text { Control } \\
\mathrm{N}=69\end{array}$ & $P$ \\
\hline Gender & & & & & $0.640^{\mathrm{a}}$ \\
\hline Male & 58 & 35 & 52 & 54 & \\
\hline Female & 13 & 12 & 19 & 15 & \\
\hline Age & & & & & $0.710^{\mathrm{a}}$ \\
\hline$<55$ & 27 & 20 & 30 & 33 & \\
\hline$\geqq 55$ & 44 & 27 & 41 & 36 & \\
\hline Smoking & & & & & $0.748^{a}$ \\
\hline Negative & 44 & 30 & 39 & 40 & \\
\hline Positive & 27 & 17 & 32 & 29 & \\
\hline Alcoholism & & & & & $0.387^{a}$ \\
\hline Negative & 54 & 37 & 47 & 48 & \\
\hline Positive & 17 & 10 & 24 & 21 & \\
\hline $\operatorname{ALT}(\mathrm{U} / \mathrm{l})^{\#}$ & $27(22,30)$ & $136(79,260)$ & $37(30,117)$ & $28(20,29)$ & $<0.001^{\mathrm{b}}$ \\
\hline AST $(\mathrm{U} / \mathrm{l}) \#$ & $34(30,44)$ & $57(44,74)$ & $45(35,186)$ & $23(21,26)$ & $<0.001^{b}$ \\
\hline GLU $(\mathrm{mmol} / \mathrm{l})^{\#}$ & $4.69(4.61,4.81)$ & $4.55(4.27,4.69)$ & $5.73(4.63,6.83)$ & $4.58(4.5,5.04)$ & $0.083^{b}$ \\
\hline
\end{tabular}

Table 5. Comparisons of the AUC of the expression of cavin-2 for subgroups. Abbreviation: Se: Sensitivity; Sp: Specificity. \#1 HCC patients with AFP levels below $200 \mathrm{ng} / \mathrm{ml}$ and Hepatitis B whose AFP levels also below $200 \mathrm{ng} / \mathrm{ml}$. \#2 HCC patients with AFP levels below $200 \mathrm{ng} / \mathrm{ml}$ and Cirrhosis whose AFP levels also below $200 \mathrm{ng} / \mathrm{ml}$

\begin{tabular}{lccccc}
\hline Group & AUC & $95 \% \mathrm{CI}$ & $P$ & $\mathrm{Se}(\%)$ & $\mathrm{Sp}(\%)$ \\
\hline HCC vs Hepatitis B & 0.865 & $0.796-0.934$ & $<0.001$ & 85.9 & 76.6 \\
HCC vs Hepatitis B\#1 & 0.870 & $0.799-0.938$ & $<0.001$ & 88.4 & 76.1 \\
HCC vs Cirrhosis & 0.901 & $0.849-0.952$ & $<0.001$ & 88.7 & 80.3 \\
HCC vs Cirrhosis $\# 2$ & 0.899 & $0.847-0.952$ & $<0.001$ & 89.9 & 78.6 \\
HCC vs Control & 0.727 & $0.643-0.812$ & $<0.001$ & 85.9 & 55.1 \\
Hepatitis B vs Control & 0.628 & $0.526-0.729$ & 0.0201 & 43.5 & 78.8 \\
Cirrhosis vs Control & 0.692 & $0.605-0.779$ & $<0.001$ & 63.8 & 69.0 \\
\hline
\end{tabular}

Fig. 3. Cavin-2 levels in plasma among subgroups. Cavin-2 expression in HCC was lower than that in hepatitis $\mathrm{B}$, cirrhosis and the controls. No differences were observed between hepatitis B and cirrhosis. The data analyzed using Oneway ANOVA. $* P<0.05$, ** $P<0.01$.

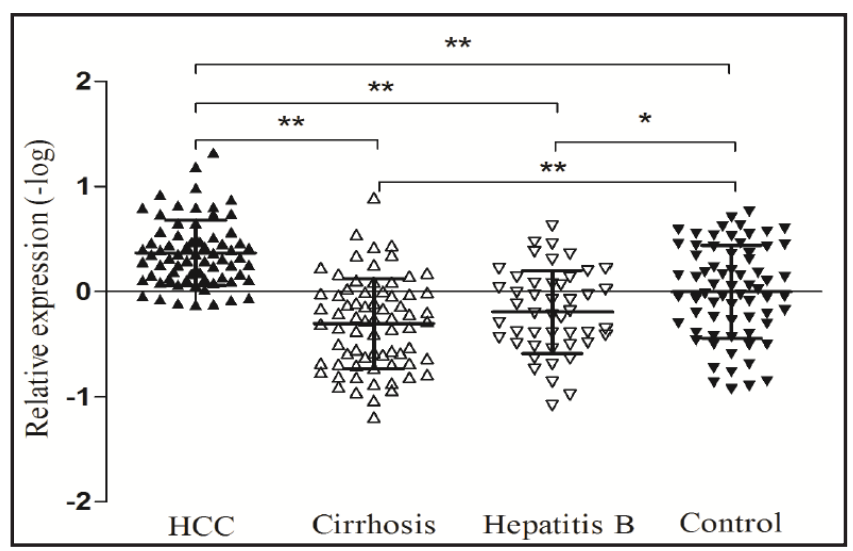

cavin-2 conferred a higher sensitivity for detecting HCC patients $(\mathrm{n}=69)$ with AFP levels below $200 \mathrm{ng} / \mathrm{ml}$ from those hepatitis B $(\mathrm{n}=46)$ (AUC=0.870, 95\%CI: 0.799-0.938) (Fig. 4 C) and cirrhosis cases ( $n=70$ ) (AUC=0.899, 95\%CI: 0.847-0.952) (Fig. 4 E) whose AFP levels were also below $200 \mathrm{ng} / \mathrm{ml}$. However, the diagnostic value of cavin-2 in another two groups was not obvious (Fig. 4 F-G). 
Fig. 4. Receiver operating characteristic (ROC) curves. A. HCC vs Controls; B. HCC vs Hepatitis B; C. HCC (AFP levels below $200 \mathrm{ng} / \mathrm{ml}$ ) vs Hepatitis B (AFP levels below $200 \mathrm{ng} / \mathrm{ml}$ ); D. HCC vs Cirrhosis; E. HCC (AFP levels below $200 \mathrm{ng} / \mathrm{ml}$ ) vs Cirrhosis (AFP levels below $200 \mathrm{ng} / \mathrm{ml}$ ); F. Hepatitis B vs Controls; G. Cirrhosis vs Controls.
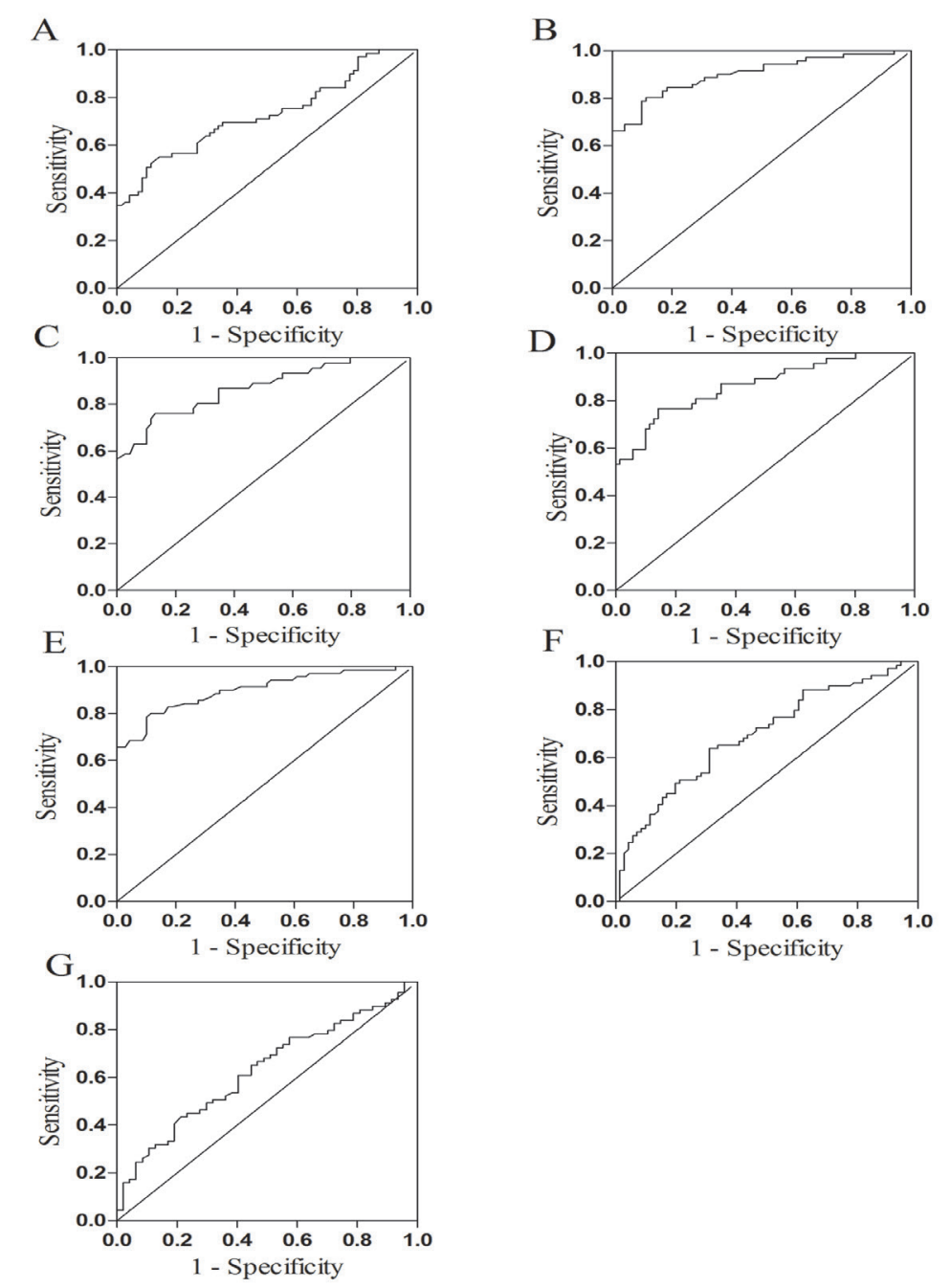

\section{Discussion}

HCC is the most common solid tumors in the global range, with highly aggressive malignancy and poor prognosis [29]. Because HCC could be diagnosed in the advanced stage after the related symptoms appear. Hence, a novel biomarker for diagnosing HCC at early stage is intensively desired in clinical. Over the past decade, numerous studies were undertaken to explore the biomarker for HCC [30]. However, the research progress remains quite slow. Caveolae are specialized plasma membrane subdomains implicated in cellular activities, such as migration, signaling, trafficking and tumorigenesis [23]. Cavins play important roles in caveolae biogenesis, regulating caveolar function and organization [31]. Evidence showed that cavin-2 (serum deprivation protein response, SDPR) was present in many cellular types, and down-regulated in several different cancers including breast, gastric, kidney, prostate and oral cancer [28,32]. In 2016, Ozturk et al. [27] found that cavin-2 could be a potential prognostic biomarker and a therapeutic target for breast cancer. Therefore, it is particularly prospective to explore the application of cavin-2 in HCC.

In our present study, we investigated the prognostic, clinical and diagnostic value of cavin-2 in HCC patients for the first time. We found that cavin-2 was down-regulated in HCC tissues to a greater extent than in corresponding noncancerous tissues, and the results 


\section{Cellular Physiology Cell Physiol Biochem 2016;39:950-960 \\ \begin{tabular}{l|l} 
and Biochemistry Published online: August 12, 2016 & $\begin{array}{l}\text { (c) 2016 The Author(s). Published by S. Karger AG, Basel } \\
\text { www.karger.com/cpb }\end{array}$
\end{tabular}}

Jing et al.: Prognostic and Diagnostic Significance of Cavin-2 in HCC

indicated that the levels of cavin-2 were related to differentiation and TNM stage. In addition, comparing with the high cavin-2 group, the decreased levels of cavin-2 were associated with a poor prognosis and a shorter survival time. We also detected the expression of cavin-2 in plasma. Results showed that the levels of cavin-2 in HCC were lower than those in the controls, the hepatitis B and the cirrhosis. This result was consistent with the tissues. However, the levels of cavin-2 in the hepatitis B and the cirrhosis were higher than the controls, the reason for the results probably was that the cavin-2 was released during the destructions of normal tissues. However, the exact reasons needed further studies to explain. As we all know, HCC is a multi-factor, multi-step and complex process. Unfortunately, despite there was statistical significance in the two groups (HCC vs hepatitis B and HCC vs cirrhosis), no remarkable difference was found between hepatitis B and cirrhosis. This result indicated that cavin-2 could not be used as an indicator to monitor the process by which hepatitis $\mathrm{B}$ developed into cirrhosis. On account of these data, we found that cavin- 2 could be used as a candidate prognostic and indicative biomarker for HCC.

Circulating RNA in plasma has been an emerging field for noninvasive diagnostic applications in HCC [33]. For the first time, we assessed the expression of cavin-2 in plasma to analysis the diagnostic value. The area under the $\mathrm{ROC}\left(\mathrm{AUC}_{\mathrm{RoC}}\right)$ elaborated that cavin-2 was helpful for differentiating HCC patients from the controls, with AUC of 0.727 and a good sensitivity of $85.9 \%$. Infected with Hepatitis B virus is one of the most important risk factors for the occurrence of HCC. ROC curve analysis showed that circulating cavin-2 in plasma had a better diagnostic value to make a distinction between HCC and hepatitis B, with AUC of 0.865 (85.9\% sensitivity, $76.6 \%$ specificity). Most importantly, cirrhosis acting as a premalignant disease of HCC, cavin-2 yielded an AUC of 0.901 (88.7\% sensitivity, 80.3\% specificity) for differentiating HCC from a total of 71 samples. These data showed that cavin-2 could be a good marker in HCC. When determining HCC cases with AFP $<200 \mathrm{ng} / \mathrm{ml}$ from the cirrhosis whose AFP levels were also below $200 \mathrm{ng} / \mathrm{ml}$, cavin-2 yielded the highest sensitivity (89.9\%). This might be useful for determining HCC in early stages when the level of AFP is lower than the diagnostic standard. But the diagnostic value in other groups was not obvious. Our data demonstrated that cavin-2 was valuable to diagnosis in liver-related disease. However, the limitation of our research was that the sample size was relatively small; the present findings therefore should be validated in trials with more cases.

Ozturk et al. [27] suggested that the deletion of cavin-2 was likely to be mediated by promoter DNA hypermethylation during breast cancer progression. In 2016, Tian et al. [34] found that cavin-2 suppressed cell proliferation and invasion in breast cancer cells by regulating epithelial-mesenchymal transition (EMT), with up-regulating epithelial markers (E-cadherin and $\beta$-catenin) and down-regulating mesenchymal markers (Vimentin and $\mathrm{N}$-cadherin). What is more, researchers suggested that transforming growth factor- $\beta$ (TGF- $\beta$ ), which can induce EMT, was blocked by cavin- 2 in breast cancer. In oral squamous cell carcinomas, Unozawa et al. [32] suggested that the ERK signaling pathway was attenuated frequently in the overexpression cavin- 2 cells. In studied cancers, cavin- 2 was a metastasis suppressor by inhibiting EMT, migration, and intravasation accompanied with promotion of apoptosis [27]. In HCC, numbers of studies reveal that it is believed that the EMT acts an important role, TGF- $\beta$ signaling pathway and ERK signaling pathway have been considered as activators of cancer progression [35-38]. Therefore, we supposed that cavin- 2 might be involved in HCC. These studies indicated that cavin-2 could suppress the development of HCC as well as other cancers. Unfortunately, the exact mechanism of cavin- 2 is still unknown in HCC.

To sum up, our research provided insights into the expression levels of cavin-2 in HCC patients for the first time. We elaborated that the expression of cavin-2 was significantly lower in HCC than that in corresponding noncancerous tissues and relation to differentiation and TNM stage. Our study indicated that cavin-2 was an independent prognostic factor of HCC patients, and comparing with the low cavin-2 group, the high one had a good prognosis and a longer survival time. Then we detected in plasma, and found that cavin-2 expression was down-regulated in HCC group, and cavin- 2 had a good diagnostic value to differentiating 


\section{Cellular Physiology Cell Physiol Biochem 2016;39:950-960 \begin{tabular}{l|l|l}
\hline DOI: 10.1159/000447803 & $\begin{array}{l}\text { C) 2016 The Author(s). Published by S. Karger AG, Basel } \\
\text { www.karger.com/cpb }\end{array}$ \\
\hline
\end{tabular} \\ Jing et al.: Prognostic and Diagnostic Significance of Cavin-2 in HCC}

HCC from cirrhosis, which was helpful to diagnose between premalignant lesions and HCC. These findings suggested for the first time that the expression of cavin- 2 could be used as a novel prognostic and diagnostic marker for HCC. However, further analysis is still essential to test exact molecular mechanism of unregulated expression of cavin-2 in HCC.

\section{Acknowledgements}

This study was supported by the National Basic Research Program of China (973 Program) (2012CB720605).

\section{Disclosure Statement}

The authors have declared that no conflict of interest.

\section{References}

1 Wang TH, Lin YS, Chen Y, Yeh CT, Huang YL, Hsieh TH, Shieh TM, Hsueh C, Chen TC: Long non-coding rna aoc4p suppresses hepatocellular carcinoma metastasis by enhancing vimentin degradation and inhibiting epithelial-mesenchymal transition. Oncotarget 2015;6:23342-23357.

2 Fan JL, Yang YF, Yuan CH, Chen H, Wang FB: Circulating tumor cells for predicting the prognostic of patients with hepatocellular carcinoma: A meta analysis. Cell Physiol Biochem 2015;37:629-640.

3 Waghray A, Murali AR, Menon KN: Hepatocellular carcinoma: From diagnosis to treatment. World J Hepatol 2015;7:1020-1029.

4 Chen KW, Ou TM, Hsu CW, Horng CT, Lee CC, Tsai YY, Tsai CC, Liou YS, Yang CC, Hsueh CW, Kuo WH: Current systemic treatment of hepatocellular carcinoma: A review of the literature. World J Hepatol 2015;7:14121420.

5 Cui SX, Zhang YS, Chu JH, Song ZY, Qu XJ: Des-gamma-carboxy prothrombin (dcp) antagonizes the effects of gefitinib on human hepatocellular carcinoma cells. Cell Physiol Biochem 2015;35:201-212.

6 Uygun Ilikhan S, Bilici M, Sahin H, Demir Akca AS, Can M, Oz, II, Guven B, Buyukuysal MC, Ustundag Y: Assessment of the correlation between serum prolidase and alpha-fetoprotein levels in patients with hepatocellular carcinoma. World J Gastroenterol 2015;21:6999-7007.

7 Li J, Wang X, Tang J, Jiang R, Zhang W, Ji J, Sun B: Hulc and linc00152 act as novel biomarkers in predicting diagnosis of hepatocellular carcinoma. Cell Physiol Biochem 2015;37:687-696.

8 You A, Cao M, Guo Z, Zuo B, Gao J, Zhou H, Li H, Cui Y, Fang F, Zhang W, Song T, Li Q, Zhu X, Yin H, Sun $\mathrm{H}$, Zhang T: Metformin sensitizes sorafenib to inhibit postoperative recurrence and metastasis of hepatocellular carcinoma in orthotopic mouse models. J Hematol Oncol 2016;9:20.

9 Shen Q, Fan J, Yang XR, Tan Y, Zhao W, Xu Y, Wang N, Niu Y, Wu Z, Zhou J, Qiu SJ, Shi YH, Yu B, Tang N, Chu W, Wang M, Wu J, Zhang Z, Yang S, Gu J, Wang H, Qin W: Serum dkk1 as a protein biomarker for the diagnosis of hepatocellular carcinoma: A large-scale, multicentre study. Lancet Oncol 2012;13:817-826.

10 Zhang G, Ha SA, Kim HK, Yoo J, Kim S, Lee YS, Hur SY, Kim YW, Kim TE, Park YG, Wang J, Yang Y, Xu Z, Song EY, Huang Z, Jirun P, Zhongtian J, Shishi Q Zhuqingqing C, Lei G, Kim JW: Combined analysis of afp and hccr-1 as an useful serological marker for small hepatocellular carcinoma: A prospective cohort study. Dis Markers 2012;32:265-271.

11 Jain D: Tissue diagnosis of hepatocellular carcinoma. J Clin Exp Hepatol 2014;4:S67-73.

12 Xie H, Ma H, Zhou D: Plasma hulc as a promising novel biomarker for the detection of hepatocellular carcinoma. Biomed Res Int 2013;2013:136106.

13 Qin LX, Tang ZY: The prognostic molecular markers in hepatocellular carcinoma. World J Gastroenterol 2002;8:385-392.

14 Hill MM, Bastiani M, Luetterforst R, Kirkham M, Kirkham A, Nixon SJ, Walser P, Abankwa D, Oorschot VM, Martin S, Hancock JF, Parton RG: Ptrf-cavin, a conserved cytoplasmic protein required for caveola formation and function. Cell 2008;132:113-124.

15 Hansen CG, Bright NA, Howard G, Nichols BJ: Sdpr induces membrane curvature and functions in the formation of caveolae. Nat Cell Biol 2009;11:807-814. 


\section{Cellular Physiology Cell Physiol Biochem 2016;39:950-960 \begin{tabular}{l|l|l}
\hline DOI: 10.1159/000447803 & $\begin{array}{l}\text { C 2016 The Author(s). Published by S. Karger AG, Basel } \\
\text { www.karger.com/cpb }\end{array}$ \\
\hline
\end{tabular} \\ Jing et al.: Prognostic and Diagnostic Significance of Cavin-2 in HCC}

16 Gupta R, Toufaily C, Annabi B: Caveolin and cavin family members: Dual roles in cancer. Biochimie 2014;107 Pt B:188-202.

17 Das M, Das DK: Caveolae, caveolin, and cavins: Potential targets for the treatment of cardiac disease. Ann Med 2012;44:530-541.

18 Nabi IR: Cavin fever: Regulating caveolae. Nat Cell Biol 2009;11:789-791.

19 Briand N, Dugail I, Le Lay S: Cavin proteins: New players in the caveolae field. Biochimie 2011;93:71-77.

20 Bastiani M, Liu L, Hill MM, Jedrychowski MP, Nixon SJ, Lo HP, Abankwa D, Luetterforst R, Fernandez-Rojo M, Breen MR, Gygi SP, Vinten J, Walser PJ, North KN, Hancock JF, Pilch PF, Parton RG: Murc/cavin-4 and cavin family members form tissue-specific caveolar complexes. J Cell Biol 2009;185:1259-1273.

21 Regazzetti C, Dumas K, Lacas-Gervais S, Pastor F, Peraldi P, Bonnafous S, Dugail I, Le Lay S, Valet P, Le Marchand-Brustel Y, Tran A, Gual P, Tanti JF, Cormont M, Giorgetti-Peraldi S: Hypoxia inhibits cavin-1 and cavin-2 expression and down-regulates caveolae in adipocytes. Endocrinology 2015;156:789-801.

22 Bai L, Deng X, Li Q, Wang M, An W, Deli A, Gao Z, Xie Y, Dai Y, Cong YS: Down-regulation of the cavin family proteins in breast cancer. J Cell Biochem 2012;113:322-328.

23 Nassar ZD, Moon H, Duong T, Neo L, Hill MM, Francois M, Parton RG, Parat MO: Ptrf/cavin-1 decreases prostate cancer angiogenesis and lymphangiogenesis. Oncotarget 2013;4:1844-1855.

24 Aboulaich N, Vainonen JP, Stralfors P, Vener AV: Vectorial proteomics reveal targeting, phosphorylation and specific fragmentation of polymerase i and transcript release factor (ptrf) at the surface of caveolae in human adipocytes. Biochem J 2004;383:237-248.

25 Hu CT, Cheng CC, Pan SM, Wu JR, Wu WS: Pkc mediates fluctuant erk-paxillin signaling for hepatocyte growth factor-induced migration of hepatoma cell hepg2. Cell Signal 2013;25:1457-1467.

26 Altintas DM, Allioli N, Decaussin M, de Bernard S, Ruffion A, Samarut J, Vlaeminck-Guillem V: Differentially expressed androgen-regulated genes in androgen-sensitive tissues reveal potential biomarkers of early prostate cancer. PLoS One 2013;8:e66278.

27 Ozturk S, Papageorgis P, Wong CK, Lambert AW, Abdolmaleky HM, Thiagalingam A, Cohen HT, Thiagalingam S: Sdpr functions as a metastasis suppressor in breast cancer by promoting apoptosis. Proc Natl Acad Sci U S A 2016;113:638-643.

28 Li X, Jia Z, Shen Y, Ichikawa H, Jarvik J, Nagele RG, Goldberg GS: Coordinate suppression of sdpr and fhl1 expression in tumors of the breast, kidney, and prostate. Cancer Sci 2008;99:1326-1333.

29 Li C, Chen J, Zhang K, Feng B, Wang R, Chen L: Progress and prospects of long noncoding rnas (lncrnas) in hepatocellular carcinoma. Cell Physiol Biochem 2015;36:423-434.

30 Tang J, Jiang R, Deng L, Zhang X, Wang K, Sun B: Circulation long non-coding rnas act as biomarkers for predicting tumorigenesis and metastasis in hepatocellular carcinoma. Oncotarget 2015;6:4505-4515.

31 Chidlow JH, Jr., Sessa WC: Caveolae, caveolins, and cavins: Complex control of cellular signalling and inflammation. Cardiovasc Res 2010;86:219-225.

32 Unozawa M, Kasamatsu A, Higo M, Fukumoto C, Koyama T, Sakazume T, Nakashima D, Ogawara K, Yokoe H, Shiiba M, Tanzawa H, Uzawa K: Cavin-2 in oral cancer: A potential predictor for tumor progression. Mol Carcinog 2016;55:1037-1047.

33 Hu X, Bao J, Wang Z, Zhang Z, Gu P, Tao F, Cui D, Jiang W: The plasma lncrna acting as fingerprint in nonsmall-cell lung cancer. Tumour Biol 2016;37:3497-3504.

34 Tian Y, Yu Y, Hou LK, Chi JR, Mao JF, Xia L, Wang X, Wang P, Cao XC: Serum deprivation response inhibits breast cancer progression by blocking transforming growth factor-beta signaling. Cancer Sci 2016;107:274-280.

35 Zhang L, Yang F, Yuan JH, Yuan SX, Zhou WP, Huo XS, Xu D, Bi HS, Wang F, Sun SH: Epigenetic activation of the mir-200 family contributes to h19-mediated metastasis suppression in hepatocellular carcinoma. Carcinogenesis 2013;34:577-586.

36 Yu Y, Xiao CH, Tan LD, Wang QS, Li XQ, Feng YM: Cancer-associated fibroblasts induce epithelialmesenchymal transition of breast cancer cells through paracrine tgf-beta signalling. Br J Cancer 2014;110:724-732.

37 Saitoh M: Epithelial-mesenchymal transition is regulated at post-transcriptional levels by transforming growth factor-beta signaling during tumor progression. Cancer Sci 2015;106:481-488.

38 Shah AD, Bouchard MJ, Shieh AC: Interstitial fluid flow increases hepatocellular carcinoma cell invasion through cxcr4/cxcl12 and mek/erk signaling. PLoS One 2015;10:e0142337. 